\title{
УДК 685.3
}

\section{НОМЕНКЛАТУРА ВИМОГ ТА СУЧАСНІ РІШЕННЯ У ВИГОТОВЛЕННІ ОРТОПЕДИЧНОГО ВЗУТТЯ}

Козарь О.П., Хімич В.І., Віктор Т.М.

\section{NOMENCLATURE OF REQUIREMENTS AND MODERN SOLUTIONS FOR THE MANUFACTURE OF ORTHOPEDIC SHOES}

Kozar Oksana, Khimych Valentin, Viktor Tetyana

У роботі сформована номенклатура вимог та представлені ортопедичні рімення щзодо виготовлення спеціалізованого взуття з ортопедичною підтримкою та корекцією, ортопедичні конструкції та матеріали для функиіонального покращення опорно-рухового апарату. Представлено новітні технології, які використовуються в галузі ортопедї $i$ можуть позитивно вплинути на роботу нижніх кінцівок.

Ключові слова: ортопедичне взуття, технологія, конструкції, устілки, амортизаційна система, матеріал, конкурентоспроможність.

The paper presents orthopedic solutions for manufacturing specialized footwear with orthopedic support and correction, orthopedic structures and materials for functional improvement of the musculoskeletal system. The newest technologies used in the field of orthopedics are presented, and can positively influence the work of the lower extremities.

Biomechanical data indicate that specialized footwear can alter the muscular activity and walking of the patient in order to reduce the load on these or those parts of the foot. The results of the research indicate that the use of new technologies contributes to the creation of such orthopedic footwear, which will provide a positive result in the treatment of orthopedic diseases.

Keywords: orthopedic shoes, technology, design, insole, cushioning system, material, competitiveness.

Відхилення від нормальної анатомічної будови і функціонування опорно-рухового апарату людини є одним 3 найбільш поширених серйозних захворювань населення. Останні дослідження показали, що частота захворювань кістково-м'язової системи серед дорослого населення становить більше 25\%. Серед 20-29 річного населення цими захворюваннями страждає 3\% осіб, до 30-39 років частота ортопедичних захворювань зростає в 2,5 рази, а до 40-49 років - ще збільшується [1,2].

Наслідки ортопедичних порушень різні, але завжди носять негативний характер. Отже, питання створення нових конструкцій ортопедичного взуття є дуже актуальним.

Так, деформація стопи викликає загальну скелетно-м'язову деформацію. При плоскостопості больові відчуття виникають не тільки в області стопи, але і в області коліна, таза, а також у різних відділах хребта, що, в кінцевому рахунку, призводить до погіршення самопочуття i зниження працездатності. Таким чином, стає зрозумілою необхідність своєчасної профілактики та лікування подібних захворювань.

Особливо варто звернути увагу на дитячі стопи. Практично у всіх новонароджених звід стопи має правильну форму, але до 6-7 років діагноз «плоскостопість» лікар-ортопед констатує приблизно у 40\% дітей. В основному відбувається ця деформація стопи із-за неправильного підбору батьками взуття своїй дитині.

Ортопедичне взуття є рішенням для людей з вродженими чи набутими проблемами стопи, 3 метою підвищення іiі функціональності і мобільності, а також запобігання деформації ніг.

Ортопедичні рішення у взуттєвому виробництві варіюються від відносно простих рішень, таких як устілки, до більш складних - ортопедичних конструкцій, таких як 
спеціалізоване взуття 3 ортопедичною підтримкою та корекцією, для функціонального поліпшення опорно-рухового апарату.

Метою статті $є$ формування номенклатури вимог та представлення ортопедичного рішення щодо виготовлення спеціалізованого взуття 3 ортопедичною підтримкою та корекцією.

Коли справа доходить до людей, які знаходяться в цій групі ризику, хороше взуття має великий вплив. Для одних можуть зникнути підстави для болю в ногах і суглобах, для інших, належне взуття може вберегти від втрати ноги або пальця. Щоб зберегти ноги здоровими ортопедичні виробники взуття завжди у пошуках нових кращих рішень і технологій, щоб допомогти своїм пацієнтам і клієнтам.

На відміну від побутового взуття, ортопедичне повинно відповідати комплексу не тільки функціональних, ергономічних та естетичних вимог, але й медичних. Забезпечення функцій руху, сприяння виконання переміщення людини в просторі залежить від конструкції низу взуття і фрикційних властивостей підошви. Говорячи про функціональні вимоги, слід враховувати, що ортопедичне взуття, як правило, експлуатується більш інтенсивно, ніж побутове, в першу чергу, в силу того, що кількість такого взуття у споживача обмежена, його неможливо доступно купити в магазині, при замовленні на фабриці вимагається час. Крім того, в ортопедичному взутті підвищеним навантаженням можуть піддаватися не ті вузли i деталі, що у побутовому.

Анатомічні зміни, які супроводжують патології, змінюють характер розподілу тиску на верх взуття. Порушення функцій стопи, патологічна хода впливають на довговічність деталей низу. Формостійкість взуття забезпечується включенням в його конструкцію каркасних деталей (в повсякденному взутті, це жорсткий задник і підносок). Однак у ортопедичному взутті використання цих деталей може бути обмежене медичними вимогами. Показники надійності готового взуття повинні відповідати вимогам ТУ 8820-016- 0316131897 «Взуття ортопедичне». До ергономічних вимог відносяться: фізіологічні, маса і гнучкість готового взуття не повинні викликати підвищених енерговитрат організму при функціонуванні нижніх кінцівок [4].

Ортопедичне взуття повинно бути по можливості легким (визначається медичними вимогами) і гнучким. У разі, якщо за медичними показаннями знижується гнучкість взуття за рахунок застосування спеціальних деталей, потовщених підошов, то повинна бути забезпечена компенсація цього показника за рахунок створення штучного перекату стопи (конструкція підошви і вкладної устілки); - антропометричні - внутрішня форма ортопедичного взуття повинна відповідати параметрам нижніх кінцівок власників i враховувати медичні вимоги, що пред'являються до взуття на ту чи іншу патологію. Виріб 3 вміщеною всередину вкладною ортопедичною устілкою має відповідати анатомічній будові стопи і забезпечувати іï нормальне функціонування. Вільне взуття не забезпечує функцію корекції патології, через ковзання стопи усередині неї, часто утворюються потертості, мозолі, надмірно тісне взуття порушує фізіологію стопи, також викликає іiі травмування, а іноді прогресування деформацій. Переходячи до серійного виробництва, усереднюються антропометричні характеристики деформованих стоп, в той же час, при підборі взуття необхідно домогтися його максимальної відповідності параметрам стопи споживача. Зокрема, при поперечній плоскостопості значною мірою варіюються поперечні розміри стопи (не тільки в області поперечного підйому, у різних людей міняються пропорції переходу від косого підйому стопи до пучків) [5]. Крім того, статичні деформації нерідко супроводжуються набряками м'яких тканин стоп, більшою мірою, ніж у здорових людей, змінюються розміри стопи протягом дня. Тому необхідно передбачити трансформацію об’єму виробу.

Гігієнічні - забезпечуються, головним чином, вибором матеріалів для верху і низу виробу, а також його конструкції. При проектуванні ортопедичного взуття даній групі вимог приділяється особлива увага. Важливими $є$ такі показники, як паропроникність, 
вологопоглинання і вологовіддача системи матеріалів верху. Вибір матеріалів багато в чому визначається медичними вимогами. Естетичні вимоги включають такі поняття, як силует, форма, матеріал, колір, конструкція і т.д. На практиці при проектуванні ортопедичного взуття естетичні показники враховуються в недостатній мірі і підпорядковані медичним вимогам. Однак, це не зовсім правильно. Наприклад, для більшості жінок краса взуття, ії відповідність загальному стилю одягу виявляється важливішим, ніж медичні функції ортопедичного призначення. Багато 3 них користуються стандартним взуттям, навіть якщо воно їм незручне і провокує подальший розвиток ортопедичних порушень. Тому потрібно приділяти увагу зовнішньому вигляду взуття, обробці, формі, комбінації матеріалів, кольору. Однак, найбільш важливими для ортопедичного взуття залишаються медичні вимоги, що визначають лікувальну ефективність створюваного виробу. Вони впливають на всі перераховані вище вимоги і відрізняються різноманітністю, залежно від виду і особливостей патології, на яку розробляється взуття.

Виробники ортопедичного взуття займаються дослідженнями направленими на створення нових конструкцій взуття та матеріалів, які будуть найкращим чином забезпечувати покращення стану своїх пацієнтів.

Одним із таких виробників є Keeping Pace, Бостон, Сполучені Штати Америки. Компанія нещодавно перейшла на модернізовані матеріали в своєму взутті Super Fabric (рис.1). Тканина популярна, тому що це дихаючий, міцний і легкий матеріал, який особливо підходить для людей з проблемами ніг.

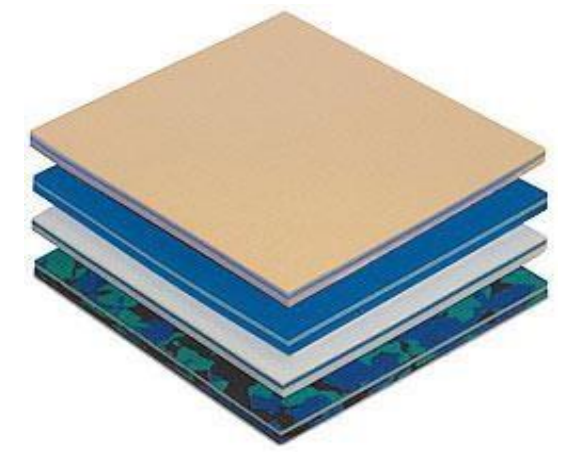

\section{Рис. 1. Матеріал Super Fabric}

Згідно 3 матеріалами, опублікованими виробником Super Fabric, матеріал $є$ накладками тканини з крихітними «захисними пластинами», які спеціально організовані. Прогалини в пластинах забезпечують гнучкість в тканині. Форма і розміри пластин, а також тканини, яку вони охоплюють, може варіюватися в залежності від деталей, необхідних для взуття. Super Fabric легша, ніж інші матеріали і водночас вона є більш міцна, ніж шкіра.

Іншим відкриттям в галузі ортопедичного взуття є розробки Foot Comfort Center, Сіетл, США. Однією $з$ нових конструкцій, випущених компанією є амортизаційна система Engineered зі спеціальною рідиною (рис.2). Ця технологічна устілка реагує на кількість сили, розміщеної на нозі і розсіює тиск.



Рис. 2. Амортизаційна система Engineered 
Матеріал зроблений зі спеціальної рідини, що може виступати поперемінно у вигляді рідини або у вигляді твердої речовини. Матеріал виготовлений з молекули ниток, стійких і дисперсних тиску при необхідності.

Таким чином, амортизація відрізняється в залежності від ваги і ходи власника.

Якщо устілка отримує більш легкий вантаж, то вона буде пружною, а при більш важкому навантаженні буде поглинати більше.

Спеціальне взуття, в поєднанні з такою підошвою яка амортизує, має стабільність в підошві, бувають ширше ширини, і мають додаткову глибину. Це все те, що потрібно для діабетичної стопи [6].

Одним 3 найбільш важливих досягнень фахівців-практиків, компанії SoleTech, Каліфорнія, США, які роблять ортопедичне взуття для пацієнтів 3 діабетом, є устілкові листи різної щільності і твердості, які виробляються як єдине ціле замість того, щоб їх склеювати в три шари (рис. 3). Призначені для користувача ортопедії устілки часто виготовляються 3 двох або трьох різних матеріалів 3 різною щільністю і твердістю, необхідних для пом'якшення і підтримки стопи. Ці листи, з різних матеріалів часто повинні бути склеєні в лабораторії. Нажаль, навіть коли все зроблено правильно в лабораторії, ці листи, що склеюються можуть розділитися у взутті пацієнта. $\mathcal{C}$ умови, де він може розшаровуватися протягом довгого часу, це тепло і волога, а всередині взуття є і одне, і інше.

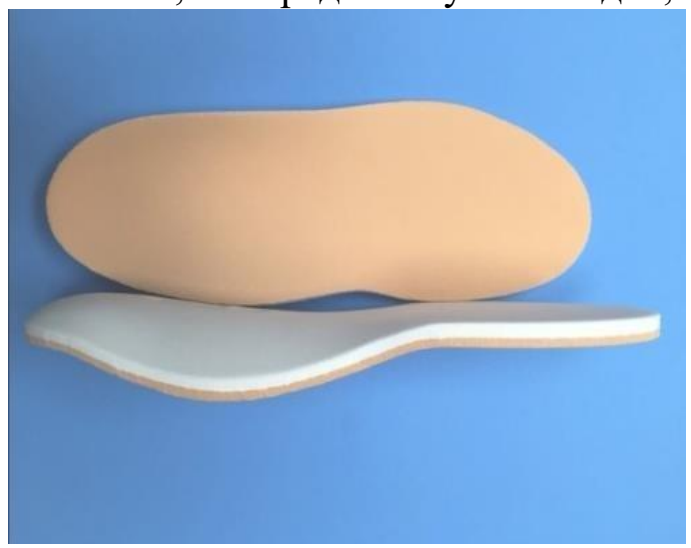

Рис. 3. Діабетичні устілки SoleTech

SoleTech створили листи, які поєднують в собі два або три матеріали різної щільності і твердості, в той час як вони виробляються таким чином, що не потребують склеювання. Виробник пропонує два шари подвійної щільності і один тришарової щільності діабетичні устілки, які ідеально підходять для пацієнтів з чутливою шкірою чи мають виразки через діабет або відсутність чутливості в кінцівках стопи. Всі вставки $є$ гіпоалергенними i безпосередньо формуються зі стопи пацієнта після застосування зовнішнього джерела тепла близько 230 градусів за Фаренгейтом, поки пластина не є м'якою і піддатливою.

Ці устілки пропонують глибоку м'яку і помірну підтримку поздовжнього склепіння стопи, щоб забезпечити підтримку чутливої стопи і допомоги до точок тиску. Їх легко обрізати і підходять в більшості для діабетичного взуття [7].

Таким чином, в даному дослідженні представлені окремі аспекти формування конкурентоспроможності та підвищення якості ортопедичного взуття через використання сучасних прогресивних технологій. У роботі сформульовано комплекс технологічних та медичних вимог до ортопедичного взуття в залежності від патології стопи, представлено ортопедичні рішення щодо виготовлення взуття з ортопедичною підтримкою та корекцією, ортопедичні конструкції та матеріали для функціонального покращення опорно-рухового апарату людини.

Дослідження захворювання ніг і біомеханіки стопи мають важливе значення та необхідні для вивчення і застосування нових технологій та механізмів, за допомогою яких можна покращити стан стопи людей, які мають ортопедичні захворювання. 


\section{Список використаних джерел}

1.Азолов В.В. Введение. Функциональная и биомеханическая диагностика в травматологии и ортопедии: сб. науч. трудов / В.В. Азолов. - Горький: НИИТО, 1989.-С.167171

2.Корнилов Н.В. Амбулаторная травматология и ортопедия. Руководство для врачей / Н.В. Корнилов, Э.Г. Грязнухин. - СПб: Оргтехиздат, 1994.-220 с.

3.Характеристика анатомо-биомеханического состояния стопы, часть I: методическое пособие . -М.: МГАЛП, 1998.

4.Яременко Д.А. Методика дослідження, діагностика и ортопедичне забезпечення при статистичних деформаціях стоп / Д.А. Яременко. - Харків, 1984.-47с.

5.Ортопедичні технології [Електронний ресурс]. - Режим доступу: http://www.gottinger.de.

6.SoleTech ортопедичні устілки [Електронний ресурс]. - Режим доступу: http://www.soletech.com.

\section{References}

1. Azolov, Vadym. 1989. Vvedenye. Funktsyonalnaia y byomekhanycheskaia dyahnostyka v travmatolohyy y ortopedyy [Functional and biomechanical diagnostics in traumatology and orthopedics]. Sbornyk nauchnykh trudov. Horkyi: NYYTO: 167-171.

2. Kornylov, Nykolai and Eduard, Hriaznukhyn. 1994. Ambulatornaia travmatolohyia y ortopedyia. Rukovodstvo dlia vrachei [Outpatient trauma and orthopedics. A guide for doctors]. SPb: Orhtekhyzdat: 220.

3. Kharakterystyka anatomo-byomekhanycheskoho sostoianyia stopu, chast II: metodycheskoe posobye. [Characteristics of the anatomo-biomechanical condition of the foot, part II: Methodical manual].1998. M.: MHALP.

4. Yaremenko, Dmytro. 1984. Metodyka doslidzhennia, diahnostyka y ortopedychne zabezpechennia pry statystychnykh deformatsiiakh stop. [The methodology of dosage, diagnostics and orthopedics is avoided with statistical deformations of the feet]. Kharkiv:47

5. Ortopedychni tekhnolohii [Elektronnyi resurs]. Available at: //https://www.gottinger.de/ orthopaedietechnik-gottinger-muenchen-zorneding-orthesen-prothesen [Accessed 19 april 2018].

6. SoleTech ortopedychni ustilky [Elektronnyi resurs]. Available at: //http://www.soletech.com [Accessed 19 april 2018].

\section{УДК 930.25=511.141}

\section{AZ ARCHIVUMOK, MINT SZERVEZETEK SZEREPE AZ EMBEREI EMLEKEZES IN FORMACIOS TEREBEN}

Movchan Katerina, Kampó I., Milesovszkij Olga

РОЛЬ АРХІВІВ ЯК СКАРБНИЦІ ДОКУМЕНТНОЇ ПАМ ЯТІ ЛЮДСТВА Мовчан К.М., Кампо I.О., Мілашовська О.I.

THE ROLE OF ARCHIVES AS HUMAN DOCUMENTARY MEMBERS

Movchan Katerina, Kampo Ilda, Milashovsky Olga

A kutatási téma relevanciája az archívumok értékelésére épül, mint a nemzet dokumentális emlék eszköze. A tanulmány célja, hogy jellemezze az archívumokat, a bolygón információs 